İş ve İnsan Dergisi I The Journal of Human and Work

Y1l | Year: Ekim | October 2014

Cilt-Sayı | Volume-Issue: 1 (1)

ss I pp: 3-19

doi: 10.18394/iid.22845

e-ISSN 2148-967X

http://dergipark.ulakbim.gov.tr/iid/

Araştırma Makalesi

\title{
Örgütsel Vatandaşılı Davranışı ve Örgütsel Bağlılık İlişkisi: Türkiye’de Yapılan Araştırmalar Üzerinden Bir Meta Analizi
}

\author{
Sait Gürbüz \\ Kara Harp Okulu
}

\author{
Özgür Ayhan " \\ Kara Harp Okulu
}

\section{MAKALE BILGGISI}

\section{Baslik:}

Örgütsel Vatandaşlık Davranışı ve

Örgütsel Bağlılık İlişkisi: Türkiye'de

Yapılan Araştırmalar Üzerinden Bir

Meta Analizi

\section{Tarihler}

Geliş 02 Haziran 2014

Düzeltme gelis 15 Ağustos 2014

Kabul 17 Eylül 2014

Anahtar Kelimeler:

Örgütsel Vatandaşlık Davranışı,

Örgütsel Bağll1ık, Psikometrik Meta

Analiz

\section{ARTICLE INFO}

Title:

Organizational Citizenship Behavior and Organizational Commitment Relationship: A Meta Analysis on Studies Conducted in Turkey

\section{Article history:}

Received 02 June 2014

Received in revised form 15 August

2014

Accepted 17 September 2014

\section{Keywords:}

Organizational Citizenship Behavior,

Organizational Commitment,

Psychometric Meta-Analysis
ÖZ

\begin{abstract}
Son yıllarda araştırmacılar tarafından yoğun ilgi gösterilen örgütsel vatandaşlık davranışının en önemli öncüllerinden birisi de örgütsel bağlllıktır. $\mathrm{Bu}$ çalışmanın amacı; Türkiye örnekleminde, örgütsel bağlılık ve örgütsel vatandaşlık davranışı arasındaki ilişkiyi inceleyen bireysel araştırmaların toplam değerini meta analizi yöntemini kullanarak tespit etmektir. Bu amaçla, Türkçe ve İngilizce yazında Türkiye örnekleminde yapılmış 31 adet müstakil görgül araştırma, Hunter ve Schmidt'in (2004) "Psikometrik Meta Analiz" yöntemi ile analiz edilmiştir. Meta analizlere dâhil edilen 31 bağımsız örneklemden $(\mathrm{N}=8708)$ elde edilen sonuçlar değerlendirildiğinde, örgütsel bağlılık ile örgütsel vatandaşlık davranışı (genel boyutları itibarıyla) arasında orta düzeyde olumlu yönde ilişki $(\rho=.36)$ olduğu görülmüştür. Bu araştırma sonuçlarının teori ve uygulamaya olan katkıları tartışılmış, ileride yapılacak araştırmalar için öneriler sunulmuştur.
\end{abstract}

Kara Harp Okulu

\section{A B S T R A C T}

Recently, one of the significant antecedents of organizational citizenship behaviour to which researcher show attention, has been organizational commitment The purpose of this study was identify the total value of the relationship between organizational citizenship behaviour and organizational commitment by using meta-analytic method in Turkish sample. For this reason, a total of 31 individual (primary) studies that have used Turkish sample in both Turkish and English organizational behaviour literature, were analyzed by using psychometric meta-analysis method suggested by Hunter and Schmidt (2004). Results based on 31 independent samples $(\mathrm{N}=8708)$ indicated a moderately strong, positive relationship $(\rho=.36)$ between organizational commitment and organizational citizenship behaviour. The theoretical and practical contributions of these findings were discussed, and directions for future research were identified.

\footnotetext{
Bu makale, Kara Harp Okulu Savunma Bilimleri Enstitüsünde Doç. Dr. Sait Gürbüz danışmanlığında yürütülen ve Mahmut Sert tarafından hazırlanan "Örgütsel adalet, örgütsel bağlılık ve örgütsel vatandaşlık davranışı ilişkisi üzerine bir meta analizi” adlı yüksek lisans tezinden üretilmiştir.

* Iletişim kurulacak yazar:

Özgür Ayhan, Kara Harp Okulu Savunma Bilimleri Enstitüsü, Ankara, Türkiye.

E-posta: oayhan@kho.edu.tr
} 


\section{GİRIŞ}

Örgütlerin hangi alanda faaliyet gösterdiklerine bakılmaksızın rakiplerine karşı rekabet üstünlüğü elde edip bu üstünlüğü sürdürebilmelerinin en önemli unsurlarından birisi de sahip oldukları insan kaynakları potansiyelleridir. Günümüzde örgütler tarafindan istihdam edilen işgörenlerin tutum ve davranışlarının örgütlerin etkinlik ve verimlilikleri üstündeki etkisi herkes tarafindan kabul edilmektedir. Araştırmacılar tarafından sebep ve sonuçları sıklıkla incelenen ve örgütsel etkinlik ve verimlilik üzerindeki etkisi yapılmış olan çalışmalarla ortaya konulan işgören davranışlarından birisi de örgütsel vatandaşlık davranışlarıdır. İşgörenlerin, iş tanımlarının ötesinde, gönüllü olarak sergiledikleri ve örgütün işleyişine olumlu katkı sağlayan ekstra rol davranışları olarak tanımlanan örgütsel vatandaşlık davranış1 - ÖVD (Organ, 1988), kavramın yazına kazandırıldığı 1983 yılından günümüze kadar araştırmacıların ilgisini çekmeye devam etmektedir. 2000'li yıllarla beraber alan yazına paralel olarak Türk araştırmacılar da ÖVD'yi ele alan çok sayıda araştırma gerçekleştirmişlerdir (örneğin Gürbüz, 2006; Şeşen \& Basım, 2012; Yılmaz \& Bökeoğlu, 2008). Yazında ÖVD’ye gösterilen bu ilginin sebebi arzu edilen örgütsel çıktılarla olan yakın ilişkisi sebebiyle araştırmacıların işgörenlerin bu tür davranışlar sergilemesine yol açan faktörleri ya da bu davranışın potansiyel öncüllerini tespit etmeye yönelmiş olmalarıdır. İlgili yazında işgörenlerin örgütsel bağlilık (ÖB) seviyeleri, ekstra rol davranışları sergilemelerinde etkili olan en önemli öncüller arasında gösterilmektedir.

Alan yazın incelendiğinde örgütsel bağlılığın, ÖVD ile arasındaki ilişkiyi ortaya koyan hem Türkiye'de hem de yabancı yazında çok sayıda nitel ve nicel bireysel çalışmanın yapılmış olduğu görülmektedir. Yöneticiler için ellerindeki en değerli kaynak olan insanın örgüt içindeki davranışlarının sebep ve sonuçlarını doğru olarak anlamak işgörenlerini örgütün hedefleri doğrultusunda yönlendirmede oldukça değerli bilgiler sağlayacaktır. Benzer şekilde, güçlü metodoloji ile yapılmış çalışmalar ile değişkenler arasındaki ilişkiler daha gerçekçi ve güvenilir olarak ortaya konulduğundan bu tür araştırmalar alanda çalışan araştırmacılar için de temel referans kaynağı olarak görülmektedir. Ancak yönetici ve araştırmacıların ihtiyaç duyduğu bu değerli ve doğru bilgilere özellikle Türkiye'deki yönetim ve örgüt araştırmalarında egemen olduğu iddia edilen “törensel görgülcülük” (Özen, 2002) anlayışının ürünü olan ve sınırlı örneklemlerle gerçekleştirilmiş bireysel çalışmaların sonuçlarına tek tek bakarak ulaşması pek mümkün gözükmemektedir. Yabancı yazında yapılmış olan çok sayıda bireysel çalışmanın çelişkili bulgularını ortadan kaldıran, çalışmaların toplam değerini ortaya koyan meta analiz çalışmaları mevcut olmasına rağmen (Dalal, 2005; Organ \& Ryan, 1995; Riketta, 2002), Türk yönetim yazınında konu ile ilgili yapılmış bir çok müstakil araştırma olmakla birlikte, ÖB ve ÖVD arasındaki ilişkinin ve etkinin tam olarak ne düzeyde olduğunu nicel olarak ortaya koyan bir meta analiz çalışmasının olmaması, bu çalışmanın temel motivasyonunu oluşturmuştur.

Bu noktadan hareketle bu çalışmanın amacı, Türkçe yazında araştırmacılar tarafından çoğunlukla tercih edilmeyen psikometrik meta analiz yöntemini kullanarak Türkiye örnekleminde; örgütsel bağlılığın, ÖVD ile arasındaki ilişkiyi inceleyen bireysel araştırmaların toplam değerini ortaya koymaktır. Tercih edilen psikometrik meta analiz yöntemiyle örneklem ve ölçek hatalarından arındırılmış gerçek değere mümkün olan en yakın düzeltilmiş ortalama etki büyüklükleri elde edilerek özellikle Türkiye yazınındaki bir boşluk doldurulmaya çalışılmıştır. Bu çalışmanın Türk yönetsel/örgütsel yazınındaki yığılmış bireysel çalışmaların sonuçlarını birleştirilip özetlemesi ve büyük resmi ortaya koyarak daha doğru ve genellenebilir bilgilere ulaşılması için yaptı̆̆ katkılar sebebiyle de hem alandaki uygulayıcılar hem de Türk yönetim ve örgüt yazını için mütevazı bir katk1 sağlayacağı beklenmektedir. $\mathrm{Bu}$ araştırmayı farklı kılan bir diğer özellik ise bu çalışmada daha önce yapılmış olan meta analiz çalışmalarından farklı olarak analize dâhil edilen bireysel çalışmaların toplulukçu kültürel değerlere sahip ülke olarak değerlendirilen Türkiye örneklemi üzerinde gerçekleştirilmiş olmasıdır.

\section{KURAMSAL CCERÇEVE}

\section{1. Örgütsel Vatandaşık Davranışı}

Barnard (1968) ve Katz'ın (1964) yaptıkları çalışmalarda, örgütsel etkinliği ve verimliliği merkeze alarak örgütlerin sahip olduğu insan kaynağını incelemiş ve bugünkü manada anladığımız örgütsel vatandaşlık davranışının kuramsal temellerini atmışlardır. Barnard (1968) ve Katz'ın (1964) örgütlerin etkinliği ve verimliliği için genel olarak tarif ettikleri davranışlar, 1983 yılında Organ ve arkadaşları tarafından örgütsel vatandaşlık davranışı olarak tanımlanarak yazına kazandırılmıştır (Bateman \& Organ, 1983; Smith, Organ ve Near, 1983). 1980'li y1llarla beraber işgörenlerin görev performanslarının ötesinde sergiledikleri davranışların örgütler için ne kadar önemli olduğunun anlaşılmasıyla beraber araştırmacıların konuya ilgisi artmış ve bu tür davranışlar farklı yazarlar tarafından bağlamsal 
performans (Borman \& Motowidlo, 1993; Motowidlo \& Van Scotter, 1994), ekstra-rol davranışı (Van Dyne vd., 1995), örgütsel spontanlık (George \& Brief, 1992) gibi temelde birbirine benzeyen farklı kavramlarla adlandırılmıştır. Ancak son yıllarda bu tür davranışları ifade etmek için ÖVD kavramının daha sı tercih edildiği görülmektedir. $\mathrm{Bu}$ araştırma kapsamında gerçekleştirilen yazın taraması sonucunda meta analize dâhil edilen çalışmaların büyük çoğunluğunun ÖVD kavramı kullanılarak yürütüldüğü belirlenmiştir.

ÖVD kavramını ilk kez kullanan Organ, ÖVD’yi “organizasyonların işlevsel verimliliğini destekleyip artıran, dolaylı veya açık olarak ödül sisteminde tanımlanmayan çalışanların gönüllülük esasına göre göstermiş oldukları davranışlar” olarak tanımlamıştır (Organ, 1988: 4). ÖVD kavramı ile görev performansı ile doğrudan ilgisi olmayan ancak örgütün sosyal mekanizmasının işleyişini kolaylaştırarak düzgün çalışmasını sağlayan davranışlar kastedilmektedir. Bu davranışlara örnek olarak; iş ile ilgili konularda çalışma arkadaşlarına yardım etme, şikâyet etmeden kuralları kabul etme, çalışma ortamını temiz ve düzenli tutma, dakik olma, molaları uzatmadan işinin başına dönme, örgüt hakkında olumlu konuşma, örgütün kaynaklarını koruyup sahip çıkma gibi davranışlar gösterilebilir (Bateman \& Organ, 1983: 588).

Yapılmış olan tanım ve örneklere dayanarak ÖVD olarak tanımlanabilecek davranışlardaki ortak noktalar olarak şunlar ifade edilebilir: Örgütün işlevselliğine biçimsel olmayan katkılar sağlaması, iş sözleşmesinde tanımlanan biçimsel rollerin dışında olması, işgörenin bu tür davranışları yerine getirip getirmemesinin gönüllülük esasına dayanmas1, işgörenin örgütü ve yöneticileri tarafından bu tür davranışlar sergilemesi için herhangi bir yaptırım ve zorlamaya maruz bırakılmamasıdır. Ayrıca bu tür davranışlar biçimsel ödül sisteminde tanımlanmadığı için ödüllendirileceğinin de garantisi yoktur (Gürbüz, 2007: 7; Organ, 1990: 46).

Organ'ın (1988) yapmış olduğu ÖVD tanımı yazında bazı eleştirilerde almıştır. Organ'ın tanımında ÖVD için iş sözleşmesinde tanımlanan biçimsel rollerin dışında, isteğe bağlı (gönüllü) olması gerektiği özellikle vurgulanmaktadır. Ancak Morrison (1994) yapmış olduğu çalışmasında biçimsel rol davranışlarıyla ekstra rol davranışlarının birbirinden kesin olarak ayrılamayacağını göstermiştir. Çalışmada iki kavram arasındaki sınırların net olmaması sebebiyle aynı davranışın bir işgören tarafından biçimsel rol davranışı olarak tanımlanırken, diğer işgören tarafından ekstra rol davranışı olarak tanımlandığ tespit edilmiştir (Morrison, 1994: 1561). Diğer bir eleştiri de ÖVD'nın resmi ödül sistemi içerisinde garanti edilmemiş olması ile ilgilidir. Yapılmış olan bazı araştırmalarda ÖVD sergileyen işgörenlerin performansının yöneticileri tarafından daha olumlu olarak değerlendirildiği ve bu işgörenlerin daha fazla maddi kaynaklar ile ödüllendirildikleri belirlenmiştir (MacKenzi, Podsakoff ve Fetter, 1991; Podsakoff \& MacKenzie, 1994).

Yapılan eleştiriler ve değişen şartlar neticesinde Organ (1997), daha önce yapmış olduğu tanımı gözden geçirerek ÖVD’yi “görev performansının gerçekleşmesini sağlayacak sosyal ve psikolojik çevreyi destekleyen davranışlar" olarak yeniden tarif etmiştir (Organ, 1997: 95). Podsakoff ve arkadaşlarına (2009) göre bu yeni tanımın bir önceki tanıma göre üç avantajı vardır: (a) Bu tanımda aralarında fark olduğu görgül olarak kanıtlanmış olan görev performansı ve ÖVD birbirinden ayrılarak aralarındaki fark korunmuştur. (b) Bu tanım Borman ve Motowidlo'nun (1993) yapmış olduğu bağlamsal performans tanımıyla çok daha tutarlı olmuştur. (c) Ayrıca bu yeni tanımla sınırlarının tespit edilmesi oldukça zor olan "resmi ödül sisteminde yer almayan" ve "gönüllülük esasına dayanan" gibi kavramlardan kaçınılmıştır (Podsakoff vd., 2009: 122).

Yazında ÖVD'nin boyutlandırmasıyla ilgili pek çok çalışma olmasına rağmen, Organ (1988) diğergamlık, nezaket, vicdanlılık, sivil erdem ve centilmenlik boyutlarından oluşan boyutlandırması hem en çok kabul göreni hem de diğer boyutlandirmalara temel oluşturmuştur. Organ'a göre; diğergamlık boyutu örgüt içerisinde çalışma arkadaşlarına görev performanslarını yerine getirmeleri konusunda karşılaştıkları problemler veya ihtiyaç duydukları konularda gönüllü olarak yardımcı olmayı ifade etmektedir. Nezaket boyutu ise, oluşabilecek olası problemleri önceden görmek ve önüne geçmek maksadiyla (Çetin, 2011) yapılacak işten etkilenmesi olası örgüt üyeleriyle önceden iletişime geçerek danışma, bilgi verme ve iş bitiminde bilgilendirme davranışlarını içermektedir (Acar, 2006). Vicdanlllık boyutu, işgörenin yerine getirmek zorunda olduğu asgari biçimsel rollerinin ötesine geçerek genel olarak örgütün faydasına olacak davranışları, herhangi bir emre veya yaptırıma maruz kalma korkusu olmadan sergilemesini ifade etmektedir. Organ (1988) dördüncü boyut olan centilmenliği, hemen hemen her örgüt içerisinde kaçınılmaz olarak var olan işle ilgili rahatsız edici durumların şikâyet edilmeden hoşgörü çerçevesinde kabul edilmesi olarak ifade etmiştir. Son olarak ÖVD’nın sivil erdem boyutu, işgörenlerin örgütün politik süreçlerine yapıcı ve sorumlu olarak katılmalarını ifade etmektedir (Podsakoff vd., 2000). 
Williams ve Anderson (1991) da ÖVD'ye dair yaptıkları çalışmada Organ'ın (1988) boyutlandırmasını temel alarak ÖVD'yi ikiye ayırmıştır. Williams ve Anderson'a (1991) göre ÖVD, hedeflenen kitle ya da guruba göre adlandırılmakta, bireye yönelik davranışlar ÖVDkişi olarak tanımlanırken, örgüte yönelik sergilenen davranışlar ise ÖVD-örgütü oluşturmaktadır. ÖVDkişi oluşturulurken diğerkamlık ve nezaket boyutlarından, ÖVD-örgütte ise vicdanlılık, centilmenlik ve sivil erdem boyutlarından yola çıkılmıştır. Bu çalışmada William ve Anderson'ın tanımladığı iki boyutlu modelin tercih edilmesini sebebi bu modelin Organ'ın (1988) beş boyutlu modelindeki tüm boyutları kapsaması ve bu sınıflandırmanın diğer ÖVD boyutlarının birçoğunu da içermesidir (Podsakoff vd., 2009). Bunun yanında işgörenlerin örgüt içerisindeki sergiledikleri vatandaşlık davranışlarının, bu davranışlarının hedef kitlesine göre farklılaştı̆̆ hem kuramsal olarak hem de görgül kanitlara dayanılarak ifade edilmektedir (Ilies, Nahrgang ve Morgeson, 2007; Ilies, Fulmer, Spitzmuller, ve Johnson, 2009). Türkiye'de yapılan bir araştırmada da beş boyutlu ÖVD ölçeğinin doğrulayıcı faktör analizi sonunda iki boyutlu modelinin beş boyutlu modele göre daha iyi uyum değerleri verdiği rapor edilmiştir (Şeşen, 2010).

\section{2. Örgütsel Bağlılık}

Yönetim ve örgütsel davranışla ile ilgili yapılan çalışmalarda araştırmacıların üzerinde en çok durduğu değişkenlerden birisi de örgütsel bağll11ktır (Mathieu \& Zajac, 1990; Meyer \& Allen, 1991; Mowday, Porter ve Steers, 1982; O`Reilly \& Chatman, 1986). Örgütsel bağlılığın yazında araştırmacıların bu kadar yoğun olarak ilgisi çekmesinin sebebi tıpkı bu araştırmanın diğer değişkeni olan ÖVD gibi örgütün yararına olan ve arzu edilen örgütsel sonuçlarla olan yakın ilişkisidir (Riketta, 2002). Daha önce ifade edildiği gibi her örgütün amacı yaptığı işte etkili ve verimli olmaktır. Örgütlerin etkili ve verimli olmanın temel şartlarından biride istihdam ettiği işgörenlerin örgütlerine olan bağlılıklarıdır (Sığrı, 2007).

İsgörenlerin örgüte olan bağlılıklarını etkileyen birçok faktör vardır. İşgörenin kişilik özellikleri, örgütsel yönetim politikaları, işgören-yönetici/lider ilişkileri, işgörenin örgüt içindeki rolünün belirli olup olmaması, örgüt içerisindeki eğitim, gelişme ve terfi olanakları, örgütsel kazanımların adil dağıtılıp dağıtılmadığı, ücret prim gibi maddi çıkarlar, işgörenin örgüte yapmış olduğu yatırımlar (emek, zaman, emeklilik hakları vb.), örgüt dışında alternatif iş olanaklarının az oluşu işgörenin örgütsel bağlllığını etkileyen faktörlerden bazılarıdır (Allen \& Meyer, 1990; Meyer \& Allen, 1991; Stum, 1999). Bu faktörlerden etkilenen işgörenlerin ÖB seviyeleri yükseldikçe işgörenlerin örgütsel amaçların gerçekleştirmek ve biçimsel rollerini yerine getirmek için daha çok çalıştıkları, ekstra rol davranışları göstermek konusunda da daha istekli oldukları yazında genel olarak kabul görmektedir (Meyer \& Allen, 2004). Örgütsel bağlılığ1 yüksek işgörenlerin ÖVD sergileme oranının daha yüksek olacağını ve işten ayrılma niyetinin ise düşük olacağını iddia edilmektedir (Gürbüz, 2011). Örgütler için en önemli maliyet kaynaklarından biri istihdam ettiği işgörenlerdeki yüksek iş gücü devir oranıdır. Örgütler özellikle sahip oldukları kaliteli işgücünü korumak için işgörenlerin bağlıllı̆ını arttırma yönünde çaba harcamaktadırlar. Yapılan çalışmalarda örgütsel bağlılığın işgücü devir oranıyla olumsuz yönde ilişkili olduğu dolayısıyla da maliyetleri azatlığı ortaya konulmuştur (Becker, Billings, Eveleth, ve Gilbert, 1996; Meyer vd., 2002; Tett \& Meyer, 1993). Örgütsel bağll1ı̆̆ı örgütlere olan bu olumlu katkıları göz önüne alındığında ne kadar önemli bir kavram olduğu ortaya çıkmaktadır.

Bağll11k konusunun örgütler için bu kadar önemli olmasına ve uzun süredir araştırmacıların ilgisini çekmesine rağmen örgütsel bağl1lı̆̆ın tanımı üzerinde tam olarak bir fikir birliğine varıldığ söylenemez (Meyer, Becker, ve Vandenberghe, 2004). Bunun sebebi farklı disiplinlerden araştırmacıların ÖB kavramına kendi disiplinlerindeki bakış açısıyla yaklaşmasıdır (Mowday vd., 1982). Yazın incelendiğinde birçok bağlılık tanımıyla karşllaşmak mümkündür (örneğin Gül, 2002). Meyer ve Herscovitch (2001) çalışmalarında farklı araştırmacıların yapmış olduğu 20 'nin üzerinde ÖB ile ilgili tanımların benzerlik ve farklılıklarını analiz etmişler ve tanımların benzerliklerinden yola çıkarak bağlılığın "temel esaslarını" belirlemişlerdir (Meyer vd., 2004). Bu esaslara göre Meyer ve Herscovitch (2001: 301) bağlılığ1 "bir veya birden fazla hedefle ilişkili olarak kişileri belirli bir davranış biçimi sergilemeleri için zorlayan güç" olarak tanımlamışlardır. $\mathrm{Bu}$ tanımda Meyer ve Herscovitch (2001) bağlılı̆̆ın "güç ve hedef/hedefler" olmak üzere iki temel esası üzerinde durmaktadırlar. Tanımda vurguladıkları hedef/hedefler kavramı ile işgörenlerin bağlılı̆̆ının yalnızca ÖB ile açıklanamayacağını işgörenlerin bağlılığının yöneticiye, iş arkadaşlarına veya işin kendisine de olabileceğini ifade etmektedirler. Tanımdaki güç kavramı ise Meyer ve Allen'in (1991) üç bileşenli bağlılık modelindeki duygusal, devam ve normatif bağlılık boyutlarını temsil etmektedir. Buna göre işgören bu ÖB boyutlarından herhangi bir veya birkaçından kaynaklanan farklı sebeplerle üyesi olduğu örgütte kalmak istemektedir (Dagenais-Cooper \& Paillé, 2012). 
ÖB konusuyla ilgili yapılan ilk çalışmalarda ÖB, işgörenlerin örgütsel amaç ve değerleri benimsemesi ve bunun sonucunda işgörenlerin işten ayrılma olasılıklarının azalmasını yansıtan tek boyutlu bir yapı olarak tanımlanmıştır (Coleman Irving ve Cooper, 1999). Meyer ve Allen (1991) bağlılığın üç bileşenli modelini örgütsel bağlılığı tek boyut olarak kavramsallaştıran çalışmaların (örneğin Mowday vd., 1982; Wiener, 1982) benzerlik ve farklılıklarını ortaya koymak için geliştirmiştir (Meyer vd., 2004). Meyer ve Allen (1984, 1991) ile Allen ve Meyer (1990) zaman içinde yaptıkları çalışmalarda örgütsel bağlılığı tek boyut olarak kavramsallaştıran çalışmalardan farklı olarak işgörenlerin örgütte olan bağlılıklarının birbirinden ayırt edilebilir farklı nedenlere dayandığını iddia etmişler ve çalışmalarında bu nedenleri duygusal, normatif ve devam bağl1lı̆ olarak isimlendirmişlerdir (Gürbüz, 2006).

Duygusal Bağlılık; "işgörenin çalıștığı örgüt ile bütünleşip, özdeşleşmesi ve örgütü ile arasında duygusal bir bağ hissetmesi" olarak tanımlanmıștır (Meyer \& Allen, 1997: 67). Duygusal bağlilık örgüttün amaç ve değerlerini kabul etmek ve örgüt üyesi olarak kalmaya istekli olmakla ilgilidir (Somers, 1995). Örgütlerine karşı duygusal olarak bir bağ hisseden işgörenlerin örgüttün amaç ve değerlerini benimsemeleri, örgütte kalmaya istekli olmaları ve örgütün amaçları doğrultusunda fazladan çaba harcamaya gönüllü olmaları beklenmektedir (Mowday, Steers ve Porter, 1979). Duygusal bağl1lık işgörenin kişisel değerleri ile örgütsel değerlerin uyumundan ortaya çıkar ve işgörenin örgüt üyesi olmaktan duyduğu hazzı ifade eder (Wiener, 1982). Duygusal bağlllıkta işgören üyesi olduğu örgütte kalmayı istediği için üyeliğini sürdürmektedir (Meyer, Allen ve Gellatly, 1990). Alan yazın incelendiğinde psikometrik ve kuramsal özellikler bakımından en güçlü bağlılık boyutunun duygusal bağl1lık olduğu görülecektir (Gürbüz \& Bekmezci, 2012).

Meyer ve Allen, 1984 yılında yapmış oldukları çalışmalarında duygusal bağlılık boyutunun yanında devam bağlılığı olarak adlandırdıkları ikinci bir ÖB boyutu tanımlamışlardır. Tanımlamış oldukları devam bağl1lığının kuramsal kökleri Becker'in (1960) taraf tutma yaklaşımına dayanmaktadır (Meyer \& Allen, 1984). Taraf tutma yaklaşımına göre işgören örgütüne yapmış olduğu yatırımları (emek, zaman, çalışma arkadaşlarıyla olan yakın ilişkiler, statü, kariyer, uzun yıllar çalışma sonucu kazanılan tecrübe ve özel yetenekler, emeklilik haklar1 vb.) kaybetmenin maliyetine katlanamayacağından örgütte kalmaya devam etmektedir (Meyer \& Allen, 1984; Obeng \& Ugboro, 2003). Devam bağl1lığı işgörenin örgütten ayrılıp ayrılmaması sonucu katlanmak zorunda kalacağ 1 maliyetlerle ilgilidir (Meyer \& Herscovitch, 2001).

İşgörenlerin devam bağlılıklarını örgüte yapmış oldukları yatırımlar ve bu yatırımlara vermiş oldukları değer etkilemektedir. İşgörenler örgüte yapmış oldukları yatırımları kendileri için ne kadar vazgeçilmez olarak görüyorlar ise örgütten ayrılma ihtimalleri de o kadar düşmektedir (Allen \& Meyer, 1990). İşgörenlerin devam bağlılığını etkileyen faktörler yalnızca yatırımlar veya işten ayrılması durumunda katlanmak zorunda kalacağı maliyetler ile ilişkili değildir. İşgörenin başka örgütlerde iş bulma alternatiflerinin az olması veya az olduğu yönündeki genel inancı da işgörenlerin devam bağlılıklarını etkilemektedir (Meyer \& Allen, 1984, 1991; Meyer, Allen ve Smith, 1993). Sonuç olarak devam bağlılığına sahip işgörenler örgütte kalmaya ihtiyaç duyarlar çünkü örgütten ayrıldıklarında çok şey kaybedecekleri gibi neredeyse kaybettiklerinin yanında hiç bir şey kazanamayacaklardır (Gürbüz \& Bekmezci, 2012).

Wiener (1982: 421), normatif bağlılık bakış açısıyla örgütsel bağlllı̆̆1 "örgütsel amaç ve hedefleri gerçekleştirmek için işgörenleri belli bir yönde davranmaya iten içselleştirilmiş normatif baskıların toplamı" olarak tanımlamıştır (Gürbüz \& Bekmezci, 2012). Wiener'a (1982) göre ÖB seviyeleri yüksek işgörenleri bu yönde davranmaya iten sebep işgörenlerin davranışlarının sonuçlarını düşünmeleri veya bir menfaat beklentisi içinde olmaları değil yaptıkları davranışların doğru ve ahlaki olduğunu düşünmeleridir. Normatif bağl1lık hisleri kuvvetli işgörenlerin örgütsel amaç ve hedefleri gerçekleştirecek yönde davranışlar sergilemelerinin veya örgütün üyesi olarak kalma yönünde irade göstermelerinin nedeni işgörenlerin bu şekilde davranmaları gerektiği yönündeki inanıșları ve yükümlülük duygularıdır (Meyer \& Smith, 2000). İşgörenlerin örgüte karşı yükümlülükleri olduğuna inanmaları kendilerini örgütte kalmaya mecbur hissetmelerine sebep olmaktadır. Ancak buradaki mecburiyet kavramı devam bağlılı̆̆ında olduğu gibi çıkara değil ahlaki duygulara (Gül, 2002) ve minnet borcuna dayanmaktadır.

\section{3. ÖVD-ÖB İLIŞKİSİ VE HIPPOTEZLER}

ÖB, örgütte istihdam edilen işgörenlerin işten ayrılma niyetlerini azaltan böylece işgörenin örgütten ayrılmasıyla ortaya çıkacak maliyetleri ortadan kaldırarak örgütsel etkinlik ve verimliliğe katk1 yapan oldukça önemli bir değişkendir (Becker vd., 1996; Tett \& Meyer, 1993; Vandenberghe \& Tremblay, 2008). Ancak Katz (1964) ve Organ (1988) örgütsel etkinlik ve verimliliğin sağlanması 
için yalnızca işgörenlerin örgütten ayrılmamasına odaklanılmasının kısa vadeli bir bakış açısı olduğunu, arzu edilen örgütsel etkinlik ve verimlilik için istikrarlı bir işgücünden daha önemli olarak işgörenlerin biçimsel rollerinin ötesinde gönüllü olarak ekstra rol davranışları göstermeleri gerektiğini ifade etmişlerdir (Katz, 1964; Organ, 1988). Her ikisi de örgütsel verimlilik için önemli olan ÖVD ile ÖB arasındaki ilişki çok sayıda araştırmaya konu olmuştur. Yapılan görgül araştırmaların sonuçlarına göre ÖB ÖVD'nin öncülüdür (Becker, 1992; Gürbüz, 2009; O’Reilly \& Chatman, 1986; Schappe, 1998; Şeşen \& Basım, 2012; Ünüvar, 2011; Van Scotter, 2000; Y1lmazer, 2010). İşgörenlerin ÖB seviyeleri yükseldikçe işgörenlerin örgütsel amaçları gerçekleştirmek ve biçimsel rollerini yerine getirmek için daha çok çalıştıkları, ekstra rol davranışları göstermek konusunda da daha istekli oldukları yazında genel olarak kabul görmektedir (Mathieu \& Zajac, 1990; Meyer \& Allen, 1997, 2004; Van Scotter, 2000).

ÖB seviyeleri yüksek işgörenlerin niçin ÖVD gibi arzu edilen davranışlar sergiledikleri, sosyal mübadele teorisi ile açıklamaktadır. Cohen ve Danny'e (2008) göre, örgütü ile ilgili olumlu deneyimler yaşayan işgörenler buna karşılık olarak örgütlerine daha fazla bağlanacak ve bunun sonucunda daha fazla ÖVD sergileyeceklerdir.

ÖB ve ÖVD arasındaki ilişkiyi inceleyen bireysel araştırmalarda çoğunlukla iki değişken arasındaki ilişkinin olumlu yönde ve anlamlı olduğu ve bağlılık seviyeleri yüksek işgörenlerin daha fazla ÖVD sergiledikleri tespit edilmiştir (örneğin Bogler \& Somech, 2004; Chen \& Francesco, 2003; Chu vd., 2006; MacKenzie, Podsakoff ve Ahearne, 1998). Ancak bazı bireysel çalışmalarda genel beklentinin aksine ÖB ile veya bazı ÖB boyutlarıyla ÖVD arasında anlamlı ilişkiler tespit edilememiştir (örneğin Williams \& Anderson, 1991; Tansky, 1993; Alotaibi, 2001).

Meyer ve Allen (1991)'in üç bileşenli bağlılık modelinde tanımlamış olduğu duygusal, devam ve normatif bağlılık boyutlarının işgörenleri örgütlerine bağlayan veya ayrılma karalarını etkileyen psikolojik durumlarını yansıttığı (Meyer vd., 1993) ve bütün boyutların işgörenlerin işten ayrılmaları ile olumsuz yönde ilişkiliyken farklı işgören davranışları (örneğin ÖVD) üzerindeki etkilerinin ise birbirinden farklı olabileceği ifade edilmişti (Meyer vd., 2004). Yapılan çok sayıdaki bireysel çalışmada duygusal bağlılık ve ÖVD arasındaki ilişkinin (Feather \& Rauter, 2004; Gürbüz, 2006; Moorman vd., 1993; Van Scotter, 2000) ve normatif bağlılık ile ÖVD arasındaki iliş̧inin (Gautam, Van Dick, Upadhyay, ve Davis, 2005; Meyer vd., 1993; Meyer vd., 2002; Nguni,
Sleegers ve Denessen, 2006; Wasti, 2005) genel olarak olumlu ve anlamlı olduğu tespit edilmiştir. Ancak duygusal bağlılık ile normatif bağlılığın ÖVD ile olan ilişkisi karşılaştırıldığında genel olarak duygusal bağlılığın normatif bağlılığa nazaran ÖVD ile daha güçlü bir ilişkisi olduğu (aksi yönde de bazı bulgular olmasına rağmen) söylenebilir (Cichy, Cha, ve Kim, 2009; Meyer vd., 2002; Pianluprasidh, 2005).

Alan yazında devam bağlılığı ile ÖVD arasındaki ilişkiyi araştıran bireysel çalışmalardan elde edilen sonuçlar bu iki değişken arasındaki ilişkinin yönü ve anlamlılığı konusunda oldukça kafa karıştırıcı sonuçlar içermektedir. Bazı araştırmalarda devam bağlılığı ve ÖVD arasındaki ilişkiler olumlu yönde anlamlı bulunurken (Nguni vd., 2006, Moorman vd., 1993; Bolat \& Bolat, 2008), bazı bireysel çalışmalarda devam bağlılığı ile ÖVD arasındaki ilişkiler olumsuz yönde, bazılarında da anlamsız olarak tespit edilmiştir (Karacaoğlu \& Güney, 2010; Meyer vd., 1993; Shore \& Wayne, 1993).

Alan yazında ki bu çelişkili bulgulara rağmen, örgütsel bağlılık ve ÖVD arasındaki ilişkileri inceleyen bireysel çalışmaların sonuçlarını özetleyen ve ortalama bir etki büyüklüğü sonucu veren meta analiz çalışmalarında ise genel ÖB boyutu ve duygusal ve normatif bağlılık boyutlariyla ÖVD-G, ÖVD-K ve ÖVD-Ö arasındaki ilişkilerin olumlu ve anlamlı olduğu tespit edilmiştir (Dalal, 2005; LePine vd., 2002; Organ \& Ryan, 1995; Riketta, 2002). Devam bağlılığı ve ÖVD arasındaki ilişkileri inceleyen meta analiz çalışmalarında ise iki değişken arasındaki ilişkinin olumsuz yönlü veya anlamsız olduğu rapor edilmiştir (Meyer vd., 2002; Organ \& Ryan, 1995).

ÖB ve ÖVD arasındaki ilişkiyi inceleyen daha önce yapılmış olan bireysel çalışmalar ve meta analiz çalışmalarının sonuçları genel olarak değerlendirildiğinde değişkenler arasındaki ilişkinin devam bağlılığı ve ÖVD arasındaki ilişkiler hariç olmak üzere genel olarak olumlu ve anlamlı olduğu söylenebilir. Geçmişte yapılmış araştırma sonuçları ve ÖB ve ÖVD ile ilgili kuramsal çerçeveden hareketle bu araştırmada test edilmek üzere geliştirilen hipotezler aşağıdadır.

Hipotez 1: Örgütsel bağlılık genel boyutuyla, ÖVD-Genel $\left(\mathrm{H}_{1 \mathrm{a}}\right)$, ÖVD-Kişi $\left(\mathrm{H}_{1 \mathrm{~b}}\right)$ ve ÖVD-Örgüt $\left(\mathrm{H}_{1 \mathrm{c}}\right)$ arasında olumlu yönde anlamlı bir ilişki vardir.

Hipotez 2: Duygusal bağlılık boyutuyla, ÖVDGenel $\left(\mathrm{H}_{2 \mathrm{a}}\right)$, ÖVD-Kişi $\left(\mathrm{H}_{2 \mathrm{~b}}\right)$ ve ÖVD-Örgüt $\left(\mathrm{H}_{2 \mathrm{c}}\right)$ arasında olumlu yönde anlamlı bir ilişki vardır. 
Hipotez 3: Normatif bağlilık boyutuyla, ÖVDGenel $\left(\mathrm{H}_{3 \mathrm{a}}\right)$, ÖVD-Kişi $\left(\mathrm{H}_{3 \mathrm{~b}}\right)$ ve ÖVD-Örgüt $\left(\mathrm{H}_{3 \mathrm{c}}\right)$ arasında olumlu yönde anlamlı bir ilişki vardır.

Hipotez 4: Devam bağlılık boyutuyla, ÖVD-Genel $\left(\mathrm{H}_{4 \mathrm{a}}\right)$, ÖVD-Kiși $\left(\mathrm{H}_{4 \mathrm{~b}}\right)$ ve ÖVD-Örgüt $\left(\mathrm{H}_{4 \mathrm{c}}\right)$ arasında olumsuz yönde anlamlı bir ilişki vardır.

\section{YÖNTEM}

\subsection{Evren ve Örneklem}

Meta analiz çalışmaları bireyler yerine meta analizin konusu ile ilgili olarak gerçekleştirilen araştırma sonuçlarının incelendiği bir yöntemdir. Meta analiz çalışmalarında analiz birimi daha önce yapılmış olan araştırmaların sonuçlarıdır (Lipsey \& Wilson, 2001). Araştırmanın evren ve örneklemini; ÖB ile ÖVD ilişkisini Türkiye bağlamında inceleyen, 2012 yılı Aralık ayına kadar yapılmış olan Türkçe ve İngilizce yayınlanmış ve yayınlanmamış çalışmalar oluşturmaktadır.

Bu kapsamda ÖB-ÖVD ilişkisini inceleyen yerli ve yabancı kaynaklarda yayınlanmış ve yayınlanmamış tüm çalışmalara ulaşılmaya çalışılmıştır. Ayrıca meta analiz çalışmalarının bir gereği olarak henüz yayın aşamasında olan veya hiç yayınlanmayacak (çekmecede kalmış) olan araştırmalara da ulaşmak için gayret gösterilmiş ve çalışmayı daha anlamlı kılmak için bu çalışmaların da meta analize dâhil edilmesine çalışılmıştır. Çalışmanın konusuyla ilgili bireysel çalışmalara ulaşabilmek için öncelikle elektronik veri tabanlarından yararlanılmıştır.

Yazın taraması yapılan elektronik veri tabanları şunlardır; Academic Search Complete, Business Source Complete, EBSCHO, Emerald, ERIC, DOAS (Directory of Open Access Journals), IEEE XploreDigital Library, JSTOR, PsycINFO, SageJournals Online, Science Direct, Springer Link, ULAKBİM (Ulusal Veri Tabanları), Taylor and Francis Online Journals, Wiley Online Library, Web of Knowledge, Web of Science. Ayrica internet arama motorlarından Google ve Yandex ile Google Scholar arama motorları da elektronik ortamda tarama yapmak için kullanılmıştır. Elektronik veri tabanlarında tarama yapılırken başlığında veya anahtar kelimelerinde şu sözcüklerin yer aldığı çalışmalar listelenmiştir: Örgütsel vatandaşlık davranışı, ekstra-rol davranışı, bağlamsal performans, örgütsel bağl1lık, duygusal bağlılık, organizational citizenship behavio(u)r, extra-role behavior, contextual performance, organizational commitment, affective commitment ve OCB. Listelenen çalışmalar tek tek incelenmiş, başlığı ve anahtar kelimeleri araştırma konusuyla uygun olduğu değerlendirilen çalışmaların özetleri okunmuştur. Bu aşamada çalışmalar bir ön elemeye tabi tutularak meta analize dâhil edilme kriterlerini taşıyabileceği değerlendirilenler, potansiyel çalışma olarak daha sonra ayrıntılı olarak incelenmek ve meta analiz kod formuna aktarılmak üzere kaydedilmiştir. Yayınlanmamış yüksek lisans ve doktora tezlerine ulaşmak için ise YÖK Tez Tarama sisteminden faydalanılmıştır. YÖK Tez Tarama Sisteminden yazarı tarafından erişimine izin verilen çalışmalar elde edilip meta analize dâhil edilip edilmeyeceği değerlendirilmiştir.

Sonuç olarak araştırma kapsamında toplam 44 adet araştırma tespit edilmiş olup, bunların 40 tanesine ulaşılabilmiştir. Ayrıntılı incelenen toplam 40 bireysel çalışmadan meta analize dâhil edilme kriterleri olan korelasyon değerlerini ya da korelasyon değerlerinin hesaplanmasında kullanılan t-testi ve $\mathrm{F}$ testi sonuçlarını raporlamış toplam 31 çalışma meta analizine dâhil edilerek sonuçları değerlendirilmiştir.

\subsection{Kodlama ve Araştırma Sonuçları}

Bu çalışmada Hunter ve Schmidt (2004: 479-487) ile Card'ın (2012: 64-81) çalışmalarından yararlanılarak araştırmanın amacına uygun olarak bir kod formu geliştirilmiştir. Kod formu üç ana başlıktan meydana gelmektedir. Birinci bölümde çalışmanın adı, yazarı, yayın yılı ve yayın türü kodlanmıştır. İkinci bölümde ise katılımcıların özellikleri (örneklem büyüklüğü, katılımcıların yüzde (\%) kaçının erkek cinsiyetine sahip olduğu ile katılımcıların çalıştıkları örgütte sahip oldukları pozisyonları (beyaz veya mavi yakalı, öğrenci vb.)) kodlanmıştır. Son bölümde çalışmanın değişkenlerine ait bilgi ve veriler (bağımlı ve bağımsız değişkenleri ölçmek için kullanılan ölçek cinsi, ölçeğin kaç boyut ve kaç maddeden oluştuğu ile ölçeklerin güvenilirliği $(\alpha$; cronbach alfa katsayıs1) kodlanmıştır. Değişkenler arasındaki gözlenen (düzeltilmemiş) korelâsyon değeri ile bu korelâsyon değerini hesaplamak için kullanılabilecek diğer istatistikî veriler de (örneğin t-testi ve ANOVA sonuçları) de son bölümde kodlanmıştır.

ÖB-ÖVD ilişkisini inceleyen 31 çalışmadaki toplam denek sayısı $\mathrm{N}=8708$ kişi, bu çalışmalardaki ortalama denek sayısı ise 281 kişidir. Bireysel çalışmalarda katılımcıların $\% \quad 70$ veya daha fazlasının erkek olduğu çalışma sayısı 12 iken, kadınlar için bu sayı 2'dir. 2 bireysel çalışmada ise cinsiyetle ilgili herhangi bir bilgi verilmemiştir.

\section{3. İşlem}

$\mathrm{Bu}$ araştırmada ÖB ile ÖVD arasındaki ilişkiyi tespit etmek maksadıyla psikometrik meta analiz 
yöntemi (Hunter \& Schmidt Metodu) kullanılmıştır. $\mathrm{Bu}$ yöntemde diğer meta analiz yöntemlerinin temel basamaklarına ilave olarak üç ana adımdan bahsedilebilir; (a) araştırmaya dâhil edilen bireysel çalışmalarda etki büyüklüğü değerini (korelâsyon katsayısını) azaltan sinırlılıklar ve hatalar tespit edilir, (b) çalışmalarda belirlenen bu hata ve sinırlılıklar ya tek tek ya da toplu olarak giderilir, (c) giderilen hata ve sinırlılıklardan sonra araştırmanın değişkenleri arasındaki gerçek ilişki bütün çalışmaları kapsayacak şekilde elde edilir (Pigott, 2006: 236).

Meta analize dahil edilen çalışmalardaki etki büyüklüklerinin aynı olması için bireysel çalışmalarda raporlanan etki büyüklükleri ek bir cinse çevrilmektedir. (Hunter \& Schmidt, 2004: 33). Bazı çalışmalarda değişkenler arasındaki korelâsyon katsayısı yerine "t-testi" ve "F-testi" sonuçları verilmiştir. $\mathrm{Bu}$ sonuçları korelâsyon katsayısına çevirmek için Hunter ve Schmidt'in (2004) önerdiği işlem basamakları uygulanmıştır. Hesaplamalar için ise Card (2012: 99) tarafindan önerilen formül esas alınmıştır. Hata koruma sayısı (fail-safe $\mathrm{N}$ ) ve Q-testi hesabı içinde bu formüllerin orijinallerinde kullanılan standartlaştırılmış farklılık (Cohen's d) "d" değerinin korelâsyon katsayısına (r) dönüştürülmesinde Borenstein ve arkadaşlarının (2009: 77) önerdiği formül kullanılmıştır.

Hunter ve Schmidt'in (2004: 81) önerdiği formül üzerinden araştırmanın bağımsız ve bağımlı değişkenleri arasında test edilen her ilişki için meta analize dâhil edilen çalışmaların örneklem büyüklükleri ve gözlenen korelâsyon katsayıları kullanılarak düzeltilmemiş ağırlıklı ortalama korelâsyon değeri (⿳亠̣⿵冂) hesaplanmıştır.

Ölçekten kaynaklanan hatalar için hata çarpanı bağımlı ve bağımsız değişkene ait ölçeklerin güvenirlik (cronbach alfa) katsayılarının çarpımının kareköküdür ( $\tilde{a}=\sqrt{r x x}) \cdot \sqrt{r y y}$ ) (Borenstein, Hedges, Higgins ve Rothstein, 2009: 343). Bu formül kullanılarak meta analize dâhil edilen her bir bireysel çalışma için ölçek hatalarından kaynaklanan kusurlar giderilerek düzeltilmiş korelâsyon (ŕ) değeri hesaplanmıştır. Düzeltilmiş etki büyüklüğü (ŕ) değeri hesaplanırken bazı çalışmalarda ölçeklerin güvenirlik katsayıları (cronbach alfa) rapor edilmediği tespit edilmiştir. $\mathrm{Bu}$ çalışmalar için meta analize dâhil edilen bireysel çalışmalardaki ölçeklerin güvenirlik katsayılarının ağırlıklı ortalaması hesaplanmış ve bu değer kullanılmıştır (Chan vd., 2008: 365).

Daha sonra Borenstein ve arkadaşlarının (2009: 343) önerdiği formül kullanılarak meta analize dâhil edilen çalışmalara ait düzeltilmiş ağırlıklı ortalama korelâsyon katsayısı (düzeltilmiş ortalama etki büyüklüğü - $\rho$ ) hesaplanmıştır. Böylece meta analize dâhil edilen çalışmalardaki ölçek ve örneklem hataları giderilerek değişkenler arasındaki gerçek ilişkiyi yansıtan mümkün olan en yakın değer elde edilmiştir.

Hatalardan kaynaklanan toplam varyans Borenstein ve arkadaşlarının (2009: 348) önerdiği formül kullanılarak hesaplanmıştır. $\mathrm{Bu}$ araştırmadaki hatalardan kaynaklanan toplam varyans ölçek ve örneklemden kaynaklanan hata varyanslarının toplamına eşittir.

Araştırmada ayrıca \% 80 güvenirlik (credibility interval) aralığı ile \% 95 güven aralığı (confidence interval) hesaplanmıştır. SS $\rho$ 'yi hesaplamak için Borenstein ve arkadaşlarının (2009: 345) önerdiği formül, $\% 80$ güvenirlik (credibility) aralığını hesaplamak için ise Hunter ve Schmidt'in (2004: 205) önerdiği formül kullanılmıştır. Düzeltilmiş ortalama etki büyüklügünün $(\rho) \% 95$ güven aralığ 1 (confidence interval) ise $\rho$ 'nin SH kullanılarak şu şekilde $\rho \pm 1.96 \mathrm{SH} \rho$ hesaplanmıştır. Standart hatayı hesaplamak için Hunter ve Schmidt (2004: 206) önerdiği formül kullanılmıştır.

Çalışmada Microsoft Excel uygulaması (MetaAnalysis Mark X) kullanılmıştır. (Steel [web], 2012).

\subsection{Bulgular}

ÖB ve ÖVD'ye ilişkin yapılan meta analiz sonuçları Tablo 1'de görülmektedir. ÖB-ÖVD-G ilişkisine yönelik meta analiz sonuçları incelendiğinde değişkenler arasındaki ilişkiyi gösteren düzeltilmiş ortalama etki büyüklüğünün $\rho=.44$ olduğu görülmektedir. ÖVD'nin alt boyutları olan ÖVDkişi ile ÖVD-örgütün ÖB ile olan ilişki düzeyine bakıldığında ise düzeltilmiş ortalama etki büyüklüğü sırasıyla $\rho=.52$ ve $\rho=.59$ olarak hesaplanmıştır. Meta analiz sonucunda ÖB'nin, ÖVD-genel, ÖVD-kişi ve ÖVD-örgüt ile orta olarak değerlendirilebilecek düzeyde olumlu yönde ilişkili olduğu tespit edilmiştir. ÖB ve ÖVD ilişkilerinde \% 80 güvenirlik aralığı alt ve üst sınırlarının hiçbirinin sıfır değerini içermemesi (ÖB-ÖVD-G .17 / .72; ÖB-ÖVD-K .30. / .73; ÖBÖVD-Ö .33 / .84), meta analizler sonucunda ulaşılan düzeltilmiş ortalama etki büyüklüğü değerlerinin anlamlı olduğunu işaret etmektedir. \% 95 güven aralığı değerleri de bu sonucu desteklemektedir. $\mathrm{Bu}$ sonuçlar araştırmanın $\mathrm{H}_{1 \mathrm{a}, \mathrm{b}, \mathrm{c}}$ hipotezlerini desteklemektedir.

Tablo 1'de, ÖB ile ÖVD-G, ÖVD-K ve ÖVD-Ö arasındaki ilişkiler incelendiğinde en güçlü ilişkinin ÖB ve ÖVD-Ö arasında olduğu görülmektedir. Bu ilişkinin gücünü gösteren düzeltilmiş ortalama etki 
Tablo 1: Örgütsel Bağlılık ve Örgütsel Vatandaşlık Davranışı İlişkisine Ait Meta Analiz Sonuçları

\begin{tabular}{llll}
\hline & ÖVD-Genel & ÖVD-Kişi & ÖVD-Örgüt \\
\hline Örgütsel Bağlılık & $.36(.44)^{\mathrm{a}}$ & $.41(.52)^{\mathrm{b}}$ & $.49(.59)^{\mathrm{c}}$ \\
\hline Duygusal Bağlıık & $.33(.42)^{\mathrm{d}}$ & $.31(.40)^{\mathrm{e}}$ & $.39(.52)^{\mathrm{f}}$ \\
\hline Normatif Bağlıık & $.27(.34)^{\mathrm{g}}$ & $.28(.36)^{\mathrm{h}}$ & $.35(.46)^{\mathrm{h}}$ \\
\hline Devam Bağlı̆ı̆̆ & $.17(.23)^{\mathrm{j}}$ & $.15(.21)^{\mathrm{k}}$ & $.17(.25)^{\mathrm{l}}$ \\
\hline
\end{tabular}

Not: $\boldsymbol{k}$; Çalışma (etki büyüklüğü) sayısı, N; Toplam katılımcı sayısı, Parantez dışındakiler; Düzeltilmemiş ağırlıklı ortalama etki büyüklüğü, Parantez içindekiler; Düzeltilmiş ağırlıklı ortalama etki büyüklüğ̈̈, $S S_{\rho} ; \rho$ 'ye ait örneklem hatasından arındırılmış standart sapma, \%80 Gr.A; \%80 Güvenirlik (Credibility) aralığı, $\% 95$ G.A; \%95 Güven (Confidence) aralı̆̆ı̈ÖV; Örgütsel vatandaşlık davranışı.

$\begin{array}{llll}a & k=18 & \mathrm{~N}=5019 & S S_{\rho}=.21 \\ b & k=7 & \mathrm{~N}=2475 & S S_{\rho}=.17 \\ c & k=7 & \mathrm{~N}=2475 & S S_{\rho}=.20 \\ d & k=22 & \mathrm{~N}=6272 & S S_{\rho}=.22 \\ e & k=12 & \mathrm{~N}=3998 & S S_{\rho}=.18 \\ f & k=11 & \mathrm{~N}=3084 & S S_{\rho}=.22 \\ g & k=16 & \mathrm{~N}=4796 & S S_{\rho}=.21 \\ h & k=9 & \mathrm{~N}=3188 & S S_{\rho}=.15 \\ l & k=9 & \mathrm{~N}=3188 & S S_{\rho}=.15 \\ j & k=16 & \mathrm{~N}=5040 & S S_{\rho}=.17 \\ k & k=10 & \mathrm{~N}=3563 & S S_{\rho}=.12 \\ l & k=10 & \mathrm{~N}=3563 & S S_{\rho}=.13\end{array}$

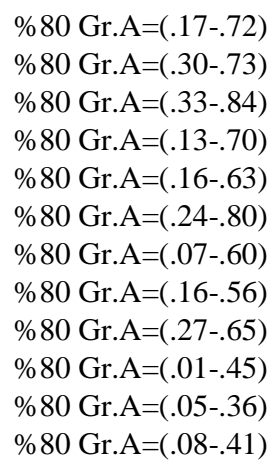

büyüklüğü değeri $\rho=.59$ olduğu tespit edilmiştir. Bunun yanında Tablo 1'de verilen meta analiz sonuçları örgütsel bağlılığın diğer iki ÖVD boyutuyla da (ÖVD-G ve ÖVD-K) kuvvetli bir ilişkisi olduğunu göstermektedir. Buna göre hem meta analiz sonuçlarına hem de yazındaki kuramsal çerçeveye dayanarak örgütsel bağlılığın ÖVD'nin oldukça önemli bir öncülü olduğu söylenebilir.

Duygusal Bağlllık ile ÖVD-G, ÖVD-K ve ÖVD-Ö ilişkisi incelendiğinde en güçlü ilişkinin Duygusal Bağlılık ve ÖVD-Ö arasında olduğu görülmektedir $(\rho=.52)$. Duygusal Bağlılık ile ÖVD-K arasındaki ilişkinin gücü ise $\rho=.40$ olarak hesaplanmıştır. ÖVD-genel'in Duygusal Bağlılık ile olan ilişkisi ise $\rho=.42$ 'dir. Tablo 1 'de görüleceği üzere $\% 80$ güvenirlik aralığı alt ve üst sınırlarının hiçbiri sıfır değerini içermemektedir. $\mathrm{Bu}$ da söz konusu ilişkilerin anlamlı olduğuna işaret etmektedir. Böylelikle $\mathrm{H}_{2 \mathrm{a} . \mathrm{b}, \mathrm{c}}$ hipotezleri de desteklenmiştir.

Araştırmanın $\mathrm{H}_{3 a, b, c}$ hipotezlerini test etmek için gerçekleştirilen meta analiz sonuçlarına göre normatif bağlılık, ÖVD-G $(\rho=.34)$, ÖVD-K ( $\rho=$ $.36)$ ve ÖVD-Ö $(\rho=.46)$ ile orta düzeyde olumlu yönde ilişkilidir. $\rho$ 'nin anlamlılığı hakkında bilgi veren \% 80 güvenirlik aralığı incelendiğinde NBÖVD arasındaki ilişkiyi inceleyen hiçbir meta analiz sonucunun güvenirlik aralığı değerlerinin sıfır değerini kapsamadığı görülmektedir. $\mathrm{Bu}$ sonuçlarda ortalama etki büyüklüğü değerlerinin $(\rho)$ anlamlı olduğunu dolayısıyla da $\mathrm{H}_{3 \mathrm{a}, \mathrm{b}, \mathrm{c}}$ hipotezlerinin desteklendiğini göstermektedir. Normatif bağlılık ve ÖVD boyutları arasındaki ilişkinin gücü incelendiğinde tıpkı ÖB ve duygusal bağlılık boyutunda olduğu gibi en güçlü ilişkinin ÖVD-Ö arasında olduğu dikkat çekmektedir ( $\rho=$ $.46)$.

Araştırmanın $\mathrm{H}_{4 \mathrm{a}, \mathrm{b}, \mathrm{c}}$ hipotezlerinde devam bağlılı̆̆ boyutunun ÖVD-G, ÖVD-K ve ÖVD-Ö boyutlarıyla olumsuz yönde anlamlı olarak ilişkili olacağ1 öngörülmüştü. Tablo 1'de sunulan meta analiz sonuçlarında beklentinin aksine devam bağlılığının, ÖVD-G $(\rho=.23)$, ÖVD-K $(\rho=.21)$ ve ÖVD-Ö $(\rho=.25)$ boyutları ile olumlu yönde ilişkili olduğu tespit edilmiştir. Devam bağlılığı ile ÖVD arasındaki ilişkilerin anlamlı olup olmadığı değerlendirildiğinde hem \% 80 güvenirlik aralığ hem de \% 95 güven aralığı değerlerinin sıfir değerini içermemesi sonuçların anlamlı olduğunu göstermektedir. Sonuç olarak meta analiz bulguları değerlendirildiğinde $\quad \mathrm{H}_{4 \mathrm{a}, \mathrm{b}, \mathrm{c}} \quad$ hipotezlerinin desteklenmediği görülmektedir.

\section{TARTIŞMA VE SONUÇ}

$\mathrm{Bu}$ çalışma psikometrik meta analiz yönteminin gücünden faydalanacak biçimde kapsamlı yazın taramasından sonra ulaşılan ve meta analizlere dâhil edilme kriterlerini taşıyan toplamda 31 bireysel çalışmayla $(\mathrm{N}=$ 8708) gerçekleştirilmiştir. Çalışmada işgörenlerin algıladıkları ÖB (ÖB, 
Tablo 2: ÖB ve ÖVD ile İlgili Yapılmış Meta Analiz Sonuçları

\begin{tabular}{|c|c|c|c|c|c|}
\hline \multirow{2}{*}{$\begin{array}{l}\text { Bağımsız } \\
\text { Değişken }\end{array}$} & \multirow{2}{*}{ Meta Analizler } & \multicolumn{4}{|c|}{ Örgütsel Vatandaşlık Davranışı } \\
\hline & & $k$ & $N$ & $\bar{r}$ & $\rho^{*}$ \\
\hline & LePine vd. (2002) & 54 & 5133 & .17 & .20 \\
\hline & Organ ve Ryan (1995) & 4 & 1614 & .18 & .23 \\
\hline Örgütsel & Meyer vd. (2002) & 22 & 6277 & .26 & .32 \\
\hline \multirow[t]{3}{*}{ Bağl1lik } & Riketta (2002) & 42 & 10747 & .19 & .25 \\
\hline & Dalal (2005) & 22 & 5582 & .22 & .28 \\
\hline & Gürbüz vd. (Cari Çalışma) & 18 & 5019 & .36 & .44 \\
\hline
\end{tabular}

Not: $k$; Çalışma (etki büyüklüğü) sayısı, $N$; Toplam katılımcı sayısı, $\bar{r}$; Düzeltilmemiș ağırlıklı ortalama etki büyüklüğü, $\rho *$; Tamamı anlamlı düzeltilmiş ağırlıklı ortalama etki büyüklüğü,

Kaynak: Dalal, 2005'ten faydalanılarak hazırlanmıştır (2005: 1249)

Duy.B., NB. ve Dev.B) düzeyleri ile örgütsel vatandaşlık davranışları (ÖVD-G, ÖVD-K ve ÖVD-Ö) arasındaki ilişkiyi inceleyen bireysel araştırmaların sonuçları birleştirilmiştir.

Araştırmanın sonucunda ÖB (ÖB, Duy.B., NB. ve Dev.B.) ve ÖVD (ÖVD-G, ÖVD-K ve ÖVD-Ö) arasındaki ilişkilerin yönü ve kuvvetine ilişkin sonuçlar elde edilmiştir. ÖB-ÖVD arasındaki ilişkiyi inceleyen ve meta analizlere dâhil edilen bireysel çalışmalarda değişkenler arasındaki ilişkilerin birbirinden çok farklı düzeylerde tespit edildiği görülmüştür (örneğin Aslan'ın (2008) çalışmasında $r=-.123$ ). Ayrıca bu bireysel çalışmaların bazılarında özellikle de devam bağlılığ ile ÖVD arasındaki ilişkiyi araştıranlarda değişkenler arasındaki ilişkileri olumsuz yönde tespit etmiş çalışmaların da olduğu belirlenmiştir. Ancak bu çalışmalar bir araya getirildiğinde ve değişkenler arasındaki ortalama ilişkiler psikometrik meta analiz yöntemiyle hesaplandığında (bakınız Tablo 1) ÖB (ÖB, Duy.B., NB. ve Dev.B.) ile ÖVD (ÖVD-G, ÖVD-K ve ÖVD-Ö) arasında olumlu yönde bir ilişkinin olduğu görülmektedir. Bununla beraber ÖB-ÖVD arasındaki ilişkilerin düzeyinin örgütsel bağlılığın genel olarak tek bir boyut ya da bağlılığın üç bileşenli modeline uygun olarak değerlendirilmesine göre farklı olduğu araştırma sonuçlarında dikkat çekmektedir.

ÖB (ÖB, Duy.B., NB. ve Dev.B.) ile ÖVD (ÖVDG, ÖVD-K ve ÖVD-Ö) arasındaki düzeltilmiş ortalama etki büyüklükleri incelendiğinde ÖVD (ÖVD-G, ÖVD-K ve ÖVD-Ö) ile en güçlü biçimde ilişkili olan bağlılık boyutu, bağlılığın tek bir boyut olarak değerlendirildiği ÖB genel boyutudur. ÖB genel boyutuyla ÖVD boyutları arasındaki ilişkiler incelendiğinde de dikkat çeken nokta ise tüm analiz sonuçları içerisinde en güçlü ilişkinin ÖB-ÖVD-Ö arasında tespit edilmiş olmasıdır $(\rho=.59)$. $\mathrm{Bu}$ bulgudan işgörenlerin ÖB düzeyleri artıkça örgütlerin ve yöneticilerin işgörenlerinden daha fazla sergilemelerini bekledikleri örgütün tamamına yönelik vatandaşlık davranışları gösterme ihtimallerinin diğer vatandaşlık davranışlarına nazaran daha fazla olduğu sonucu çıkarılabilir.

ÖVD (ÖVD-G, ÖVD-K ve ÖVD-Ö) ile Meyer ve Allen'in (1991) üç bileşenli bağlılık modeli arasındaki ilişkiler değerlendirildiğinde ise ÖVD boyutlarıyla en kuvvetli ilişkinin duygusal bağlılık boyutu arasında olduğu görülmektedir. Duygusal bağlılığ1 sirasıyla normatif ve devam bağlılı̆̆1 boyutları izlemektedir.Ancak meta analiz sonuçlarındaki düzeltilmiş ortalama etki büyüklükleri, duygusal ve normatif bağlılık boyutları ile ÖVD boyutları arasındaki ilişki açısından değerlendirildiğinde her iki bağlılık boyutuyla ÖVD boyutları arasındaki etki büyüklükleri farkının olukça düşük olması normatif bağlılığında işgörenlerin ÖVD sergilemelerinde duygusal bağlılık kadar önemli olduğunu göstermektedir. Meta analiz bulgularından normatif bağlılığın işgörenlerin örgüte yönelik vatandaşlık davranışı sergilemelerinde duygusal bağlılıkla beraber oldukça etkili olduğu sonucu çıkarılabilir (Duy.B-ÖVD-Ö, $\rho=.52$; NB-ÖVD-Ö, $\rho=.46$ ).

Devam bağlılı̆̆ ile ÖVD boyutları arasında, duygusal ve normatif bağlılığa göre daha zayıf bir ilişki söz konusudur. Devam bağlılığı ile ÖVD 
(ÖVD-G, ÖVD-K ve ÖVD-Ö) arasındaki ilişki araştırmanın dördüncü hipotezindeki beklentinin aksine olumlu yönde anlamlı olarak tespit edilmiş ve sonuç olarak araştırmanın $\mathrm{H}_{4}$ hipotezi reddedilmiştir.

Sonuç olarak bu araştırma sonunda ulaşılan meta analiz sonuçları ÖB (ÖB, Duy.B. ve NB ) ve ÖVD (ÖVD-G, ÖVD-K ve ÖVD-Ö) arasındaki orta düzeyde olumlu yönde ilişki olduğunu ortaya koymaktadır. Dev.B ile ÖVD boyutları arasında olumlu yönde ve anlamlı bir ilişki söz konusudur. Ancak değişkenler arasındaki ilişsinin kuvveti diğer bağlılık türleriyle karşıllaştırılınca oldukça zayıf kalmaktadır. ÖB-ÖVD arasındaki ilişkiyi veren bu araştırmanın sonuçlarının geçmişte yapılmış diğer meta analiz sonuçlarıyla değişkenler arasındaki ilişkilerin orta düzeyde olumlu yönde olması açısından tutarlı olmasına rağmen düzeltilmiş ortalama etki büyüklüğü değerlerinin büyüklüğü bakımından bu çalışmayla geçmiște yapılmış çalışmalar arasında fark olduğu dikkat çekmektedir. $\mathrm{Bu}$ sebeple bu çalışmada ÖB-ÖVD için ulaşılan düzeltilmiş ortalama etki büyüklüğü $(\rho=.44)$ ile Türkiye dışındaki örneklemlerde daha önce yapılıış olan meta analiz çalışmalarında ÖB-ÖVD için tespit edilen etki büyüklükleri Tablo 2'de verilmiştir.

Tablo 2'de ÖB ve ÖVD arasındaki ilişkiyi yabancı yazında inceleyen geçmişte yapılmış meta analiz sonuçları (Dalal, 2005; LePine vd., 2002; Meyer vd., 2002; Organ \& Ryan, 1995; Riketta, 2002) bu çalışmayı da kapsayacak şekilde sunulmuştur. Tablo-2'de geçmişte yapılmış olan meta analiz sonuçlarının ÖVD ile ÖB arasında orta düzeyde anlamlı bir ilişkiyi ortaya koyduğu görülmektedir. Aynı şekilde çalışma sonucunda ulaşılan etki büyüklükleri değerleri de ÖB ile ÖVD arasında orta düzeyde anlamlı bir ilişki olduğunu göstermektedir. Bununla beraber bu çalışmada ulaşılan etki büyüklükleri, geçmişte yapılmış olan çalışmalarla kıyaslandığında ÖB için ortalama 0.2 puan daha yüksek olduğu göze çarpmaktadır.

Daha öncede ifade edildiği gibi geçmişte yapılmış meta analizlere dâhil edilen bireysel çalışmaların büyük çoğunluğu bireyci ve belirsizlikten kaçınmayan kültürel değerlere sahip Kuzey Amerika ülkelerinde gerçekleştirilmiş araştırmalardan oluşmaktadır (Dalal, 2005; Meyer vd., 2002; Organ \& Ryan, 1995; Riketta, 2002). Bu çalışma ise toplulukçu kültürel değerleri yansitan bir ülke olan Türkiye de gerçekleștirilmiştir.

Buradan çıkarılacak en önemli sonuç alan yazına hâkim olan batı kültürel değerlerine sahip ülkelerde gerçekleștirilmiş olan araştırma sonuçlarının özellikle Türkiye gibi bu kültürel değerlerden farklı kültürel değerlere sahip (örneğin toplulukçu) ülkeler için genellemesinin yapılırken kültürel bağlamın önemli olduğunun ortaya konulmuş olmasıdır. Devam bağlılığı ile ÖVD arasında olumlu yönde anlamlı çıkan etki büyüklüğünün en önemli sebebi olarak bu bağlamsal farkl1lık gösterilebilir. Paine ve Organ (2000) toplulukçu kültürlerde ÖVD daha fazla görülmesini bu kültürde yetişmiş bireylerin ait oldukları gruba sıkı bir şekilde bağlı olmalarına ve bireylerin grubun amaçları için gösterdikleri özgecilik davranışlarının toplulukçu kültüre sahip toplumlarda yaygın ve kabul gören bir davranış olmasına bağlamışlardır. Toplulukçu kültürleri bireyci kültürlerden ayıran temel özellik toplulukçu kültürlerde kişi kendini bir grubun (örneğin aile, örgüt vb.) parçası olarak görür, grubun amaç ve önceliklerini kendi kişisel hedeflerinden önde tutarlar (Wasti \& Erdil, 2007: 40). Bu nedenle toplulukçu kültürel değerlere sahip işgörenler grubun (örgütün) amaçlarını gerçekleştirmek ve grubun kendilerinden beklentilerini karşılamak için ekstra çaba harcayarak bireyci kültürel değerlere sahip işgörenlere göre daha fazla ÖVD sergileyebilmektedirler.

Devam bağlılı̆̆ı ile ÖVD boyutları arasındaki orta düzeyde anlamlı ilişkinin olası bir başka açıklaması ise Türkiye gibi işsizlik oranının yüksek olduğu ülkelerdeki işgörenler başka örgütlerde iş bulma alternatiflerinin az olduğunu düşündüklerinde de örgütlerine karşı yüksek düzeyde devam bağlılı̆̆ Ancak işgörenlerin kendilerini örgütte kalmaya mecbur hissetmeleri ÖVD sergilemeyecekleri anlamı taşımamalıdır. Meyer ve Allen'e göre (1991) örgütsel bağl1lığın üç boyutu birbirinden ayrı unsurlar olarak değerlendirilse de bu durum örgüt içerisinde işgörenlerin üç psikolojik durumu (istek, yükümlülük ve ihtiyaç) farklı derecelerde olmak üzere aynı anda tecrübe edemeyecekleri anlamına gelmemektedir. Türkiye'de gerçekleştirilen bireysel çalışmalardaki denek gruplarını oluşturan işgörenlerin örgütten ayrılmama konusundaki hisleri yüksek düzeyde bir zorunluluk içerse de bu işgörenler aynı zamanda değişen oranlarda olmak üzere örgütlerine karşı duygusal bağlllık ve yükümlülükte hissedebilmektedirler. Böylece işgören yüksek düzeyde devam bağlllığına sahip olsa da diğer bağlılık boyutlarına kıyasla daha az da olsa ÖVD sergileyebilmektedir. Bu çalışmada ÖVD boyutlarıyla duygusal ve normatif bağll1ık boyutlarının oldukça yüksek düzeyde ilişkili olması bu varsayımı destekler niteliktedir.

Bu çalışmadaki meta analizlere dâhil edilen bireysel çalışmaların toplulukçu kültürlerde gerçekleştirilen çalışmalar olması sebebiyle bu araştırmadan elde edilen analiz sonuçlarının geçmişteki meta analiz çalışmalarının eksik kalan tarafını tamamlayarak 
yazındaki önemli bir boşluğu doldurduğu böylece ÖB ile ÖVD arasındaki ilişkilerin alandaki akademisyenler tarafindan daha net görülmesine katkı yaptığı da söylenebilir.

Ayrıca bu araştırma sonuçlarının geçmişteki meta analiz sonuçlarıyla beraber değerlendirilmesi halinde ülkelerin sahip olduğu kültürlerarası farklılıkların örgütsel davranış alanında oynadığı rolün daha iyi anlaşılmasına yararı olacağı, mevcut kuram ve modellerin geliştirilmesi açısından da alan yazına katkı sağlayabileceği ifade edilebilir.

Çalışmanın uygulamaya katkısına gelinecek olunursa; araştırma sonuçları ÖB ile ÖVD arasındaki ilişki açısından en güçlü ilişsinin genel ÖB ile ÖVD-Ö arasında olduğu tespit edilmiştir. Değişkenler arasındaki yüksek düzeydeki ilişki dikkat çekmektedir. Geçmişte yapılmış meta analiz çalışmaları ile çok sayıda bireysel çalışmanın sonuçlarının da ortaya koyduğu gibi işgörenlerin sergilemiş oldukları örgüte yönelik vatandaşlık davranışları örgütlerin etkinlik ve verimliliklerine önemli katkılar sağlamaktadır. İşgörenlerin sergiledikleri ÖVD'lerin örgütlerin etkinlik ve verimliliklerine olan bu önemli katkıları göz önüne alındığında ÖB-ÖVD-Ö arasında yüksek düzeyde ve olumlu yöndeki ilişkinin ortaya konulmuş olması örgütler ve yöneticileri için elde tutmak istedikleri işgörenlerinin örgüte olan bağl1lıklarını arttırmanın ya da en azından var olan bağlllık düzeylerini koruyacak tedbirleri almalarının ne kadar önemli olduğunu göstermektedir.

Devam bağlılı̆̆ ile ÖVD boyutları arasında duygusal ve normatif bağlıllı̆a göre daha zayıf bir ilişkinin olduğu ve bu ilişkinin olumlu yönde anlamlı olduğunun tespit edildiği önceki bölümde ifade edilmişti. Örgüt içinde devam bağlılığına sahip çalışanlarının daha fazla ÖVD sergilemelerini arzu eden yöneticiler bu işgörenlerinin duygusal ve normatif bağlılık düzeylerini artıracak tedbirler alarak bu çalışanların daha fazla ÖVD sergilemelerini sağlayabilirler. Çünkü her çalışan örgütüne aynı anda ve farklı düzeylerde olmak üzere hem duygusal hem normatif hem de devam bağlılığını aynı anda tecrübe edebilmektedirler. Bu sebeple yöneticiler kendilerini örgütte kalmaya mecbur hisseden çalışanlarını tespit ederek özellikle Türkiye gibi toplulukçu kültürel değerlere sahip bir ülkede çok daha az bir çabayla bu işgörenlerinin örgüt ve yöneticilerine olan duygusal ve normatif bağlilıklarının artmasına sebep olabilirler. Bunun sonucunda da bu çalışanlar kendilerinden beklenen görev tanımlarının ötesinde daha fazla çaba harcayarak örgütlerinin etkinlik ve verimliliklerine katkıda bulunabilirler.

$\mathrm{Bu}$ çalışmada ulaşılan meta analiz sonuçlarının değerlendirilmesi ve sonuçların olası neden ve açıklamaları ile bu sonuçların hem yazına hem de uygulayıcılara olan katkına değinilmiştir. Ancak her çalışmada olduğu gibi bu çalışmada da bazı kısıtlar söz konusudur. Bu sebeple meta analiz sonuçlarının değerlendirilmesi yapılırken aşağıda sıralanan kısıtların da göz önünde tutulmasının uygun olacağı düşünülmektedir. Ayrıca bu kısıtlara yönelik olarak tespit edilen husus ve öneriler de meta analiz konusuna ilgi duyabilecek araştırmacılar için sunulmuştur.

İlk olarak; araştırmaya sadece Türkçe ve İngilizce yazılmış çalışmalar dâhil edilmiştir. İleride yapılacak çok yazarlı (farklı ülkelerden) çalışmalarla başka dillerde yayınlanmış çalışmalarında meta analizlere dâhil edilmesi sağlanarak daha geniş bir örnekleme ait sonuçlara ulaşılabilir. Ayrıca, meta analize dâhil edilen çalışmalar kullanılan elektronik veri tabanları ve kullanılan anahtar kelimeler sonucu ulaşılan araştırmalar ile sınırlıdır. Arama kriterleri sonucunda ulaşılamayan ve yayınlanmamış çalışmalara ulaşılamaması araştırma için bir kısıt oluşturmaktadır.

Psikometrik meta analiz çalışmalarında bireysel çalışmalardaki düzeltilen hatalardan birisi de aralık kısıtı (range restriction) hatasıdır. Bu çalışmada bireysel araştırmalarda bu hatayı düzeltecek yeterli veri olmadığ 1 için bu hata giderilememiştir. $\mathrm{Bu}$ sebeple düzenleyici etki analizlerine ihtiyaç olup olmadığına karar verilememiştir. İleride yapılacak meta analiz çalışmalarında bu olası düzenleyici değiş̧kenlerin neler olabileceği (örn: kullanılan ölçek türü, deneklerin yaş, eğitim veya işyerinde çalışma süreleri, işgörenlerin mavi ya da beyaz yakalı olmaları gibi) tespit edilerek sonuçları ortaya konmalıdır. Düzenleyici değişkenlerin uygun tespit edilip sonuçlarının doğru bir şekilde paylaşılması hem alandaki uygulayıcıların hem de araştırmacıların ÖB ve ÖVD arasındaki ilişkileri daha gerçekçi değerlendirmesini ve yorumlamasına yardımcı olacaktır.

Bireysel çalışmalara ulaşma safhasında karşılaşılan zorlukların yanında ulaşılan çalışmalarında bazılarında korelasyon değerlerine rastlanamamıştır. Psikometrik meta analiz yönteminin gereği olarak değişkenler arasındaki ilişkiyi gösteren etki büyüklüğü değeri olarak korelâsyon değerleri kullanılmaktadır. Bazı bireysel çalışmalarda korelasyon değeri verilmediği için $\mathrm{t}$ testi ve $F$ testi sonuçları kullanılarak korelâsyon katsayıları hesaplanmıştır.Ancak bazı çalışmalarda ise hiçbir istatistiki veriye ulaşılamamıştır. Bu sebep analize dahil edilecek çalışmaların sayısı azalmıştır. İleride meta analiz konusunda çalışmak isteyen araştırmacıların bu gibi durumlarla 
karşılaşmamaları için yazarların konularıyla ilgili temel istatistikî bilgileri çalışmalarının içinde mutlaka vermeleri, bunun çalışmanın akışına uygun olmaması durumunda en azından çalışmalarının sonunda ek olarak tablolar halinde sunmalarının uygun olacağı düşünülmektedir.

Yayınlanmamış çalışmalara ulaşmak ve bu çalışmaları analize dahil etmek bu çalışmada karşılaşılan en büyük kısıtlardan biri olarak düşünülmektedir. YÖK'ün veri tabanında yer alan ancak erişim izni olmayan üç çalışma analize dahil edilememiștir. Dâhil edilemeyen çalışmalara ulaşmak için gönderilen elektronik postalara ise yazarlar tarafindan herhangi bir geri bildirimde bulunulmamıştır. İleride yapılacak çalışmalarda bu çalışmaların da meta analizlere dâhil edilmesi sonuçların daha sağlıklı olması açısından oldukça önemlidir. Bununla beraber araștırmacıların ulaşılmasına izin verilmeyen tezlere ulaşamayacaklarını, yayın yanlılığını azaltmak maksadıyla çekmecede kalmış çalışmalara ulaşmak için gönderdikleri elektronik postalara cevap alamayacaklarını baştan bilmeleri ve buna hazırlıklı olmaları da yararlı olabilir.

Tüm bu kısıtlara rağmen yapılmış olan bu meta analiz çalışması ile hem Türkiye'deki hem de geçmişte yapılmış meta analiz çalışmalarından farklı olarak analizlere dâhil edilen bireysel çalışmaların büyük çoğunluğunu toplulukçu kültürel değerlere sahip ülkelerde yapılmış araştırmaların oluşturduğu ÖB ve ÖVD ilişkisini inceleyen bireysel çalışmaların sonuçları özetlenmiş, bu çalışmalardaki örneklem ve ölçek hataları giderilerek değişkenler arasındaki gerçek ilişkiye mümkün olduğunca yakın değerler elde edilmiştir. Buna göre bu araştırma sonuçları Türkiye örneklemi için ilk defa yapılıyor olması sebebiyle ÖB ve ÖVD arasındaki ilişkinin büyük resmini görmemizi sağlayarak yerli yazında önemli bir boşluluğu doldurmuştur. $\mathrm{Bu}$ araştırmanın sonuçları geçmiş yıllarda yapılmış olan meta analiz sonuçlarıyla beraber değerlendirildiğinde alan yazındaki ÖB ve ÖVD ilişkisini açıklayan mevcut teorilerin geliştirilmesine katkı sağlayacağı düşünülmektedir. Ayrıca araştırmanın bundan sonra yapılacak çalışmalara veri sağlayacağı ve benzer meta analiz çalışmalarına da yöntem olarak model olabileceği değerlendirilmektedir.

\section{KAYNAKÇA}

Acar, A. Z. (2006). Örgütsel yurttaşlık davranış1: Kavramsal gelişimi ile kişisel ve örgütsel etkileri. Doğuş Üniversitesi Dergisi, 7(1), 1-14.

Allen, N. J. \& Meyer J.P. (1990). The measurement and antecedents of affective, continuance and normative commitment to the organization. Journal of Occupational Psychology, 63(1), 1-18.

Alotaibi, A. G. (2001). Antecedents of organizational citizenship behavior: A study of public personnel in Kuwait. Public Personnel Management, 30(3), 363376.

Aslan, Ş. (2008). Örgütsel vatandaşlık davranışı ile örgütsel bağlılık ve mesleğe bağlllık arasındaki ilişkilerin araştırılması. Yönetim ve Ekonomi, 15(2), 163-178.

Barnard, C. I. (1968). The Functions of the Executive (2.Bask1), Cambridge, Mass: Harvard University Press.

Bateman, T. S. \& Organ, D. W. (1983). Job satisfaction and the good soldier: The relationship between affect and employee citizenship. Academy of Management Journal, 26(4), 587-595.

Becker, T. E. (1992). Foci and bases of commitment: Are they distinctions worth making? Academy of Management Journal, 35(1), 232-244.

Becker, H. S. (1960). Notes on the concept of commitment. The American Journal of Sociology, 66(1), 32-40.

Becker, T. E., Billings, R. S., Eveleth, D. M., \& Gilbert, N. L. (1996). Foci and bases of employee commitment: Implications for job performance. Academy of Management Journal, 39(2), 464-482.

Bogler, R. \& Somech, A. (2004). Influence of teacher empowerment on teachers' organizational commitment, professional commitment and organizational citizenship behavior in schools. Teaching and Teacher Education, 20(3), 277-289.

Borenstein, M., L., Hedges, V., Higgins, J.P.T., \& Rothstein, H.R. (2009). Introduction to meta-analysis. UK: John Wiley and Sons.

Bolat, O. İ. \& Bolat, T. (2008). Otel işletmelerinde örgütsel bağl1lık ve örgütsel vatandaşlık davranış1 ilişkisi. Balıkesir Üniversitesi Sosyal Bilimler Enstitüsü Dergisi, 11(19), 75-94.

Borman, W. C. \& Motowidlo, S. J. (1993). Expanding the criteriondomain to include elements of contextual performance. İçinde N. Schmitt ve W. C. Borman (Ed.), Personnel Selection in Organizations (pp. 7198), San Francisco. 
Card, N.A. (2012). Applied Meta-Analysis for Social Science Research. New York: The Guilford Press.

Chan, D.K-S., Lam, C.B., Chow, S.Y., \& Cheung, S.F. (2008). Examining the job-related, psychological and physical outcomes of workplace sexual harassment: A meta-analytic review. Psychology of Women Quarterly, 32, 362-376.

Chen, Z. X. \& Francesco, A.M. (2003). The relationship between the three components of commitment and employee performance in China. Journal of Vocational Behavior, 62(3), 490-510.

Cichy, R. F., Cha, J., \& Kim, S. (2009). The relationship between organizational commitment and contextual performance among private club leaders. International Journal of Hospitality Management, 28, 53-62.

Chu, C., Lee, H. \& HSU, H.M. (2006). The impact of social support and job stress on public health nurses' organizational citizenship behaviors in rural Taiwan. Public Health Nursing, 23(6), 496-505.

Cohen, A. \& Danny, K. (2008). Individual values and social exchange variables examining their relationship to and mutual effect on in-role performance and organizational citizenship behavior. Group and Organization Management, 33(4), 425452.

Coleman, D. F., Irving, G. P., \& Cooper, C. L. (1999). Another look at the locus of control-organizational commitment relationship: It depends on the form of commitment. Journal of Organizational Behavior, 20(6), 995-1001.

Çetin, F. (2011). Örgütsel vatandaşlık davranışlarının açıklanmasında örgütsel bağlılık, iş tatmini, kișilik ve örgüt kültürünün rolü (Yayınlanmamış Doktora Tezi). Ankara Üniversitesi Sosyal Bilimler Enstitüsü, Ankara.

Dalal, R.S. (2005). A meta-analysis of the relationship between organizational citizenship behavior and counterproductive work behavior. Journal of Applied Psychology, 90(6), 1241-1255.

Dagenais-Cooper, V. \& Paille, P. (2012). Employee commitment and organizational citizenship behaviors in the hotel industry: Do foci matter? Journal of Human Resources in Hospitality and Tourism, 11, 303-326.

Feather, N. T. \& Rauter, K.A. (2004). Organizational citizenship behaviours in relation to job status, job insecurity, organizational commitment and identification, job satisfaction and work values. Journal of Occupational and Organizational Psychology, 77(1), 81-94.

Gale, B. (2010). Örgütsel vatandaşlık ve örgütsel bağl1lık ilişkisi (Yayınlanmamış Yüksek Lisans Tezi). Gaziosmanpaşa Üniversitesi Sosyal Bilimler Enstitüsü, Tokat

Gautam, T., Van Dick, R., Upadhyay, N., \& Davis, A.J. (2005). Organizational citizenship behavior and organizational commitment in Nepal. Asian Journal of Social Psychology, 8, 305-314.

George, J. M. \& Brief, A. P. (1992). Feeling good - doing good: A conceptual analysis of the mood at workorganizational spontaneity relationship. Psychological Bulletin, 112(2), 310-329.

Gül, H. (2002). Örgütsel bağl1lık yaklaşımlarının mukayesesi ve değerlendirilmesi. Ege Academic Review, 2(1), 37-56.

*Gürbüz, S. (2006). Örgütsel vatandaşlık davranışı ile duygusal bağlılık arasındaki ilişkilerin belirlenmesine yönelik bir araștırma. Ekonomik ve Sosyal Araştırmalar Dergisi, 3(1), 48-75.

Gürbüz, S. (2007). Yöneticilerin örgütsel vatandaşlık davranışlarının iş tatmini ve algıladıkları örgütsel adalet ile ilişkisi (Yayınlanmamış Doktora Tezi). İstanbul Üniversitesi Sosyal Bilimler Enstitüsü, İstanbul.

Gürbüz, S. (2009). Some possible antecedents of military personnel organizational citizenship behavior. Military Psychology, 21, 200-215.

Gürbüz, S. (2011). Stratejik insan kaynakları yönetiminin örgütsel bağlllığa ve iş tatminine etkisi: İnsan kaynakları yöneticileri üzerinde bir araştırma. Atatürk Üniversitesi Sosyal Bilimler Enstitüsü Dergisi, 15(2), 397-418.

Gürbüz, S., \& Bekmezci M. (2012). İnsan kaynakları yönetimi uygulamalarının bilgi işçilerinin işten ayrılma niyetine etkisinde duygusal bağl1lığın aracılık ve düzenleyicilik rolü. İstanbul Üniversitesi İşletme Fakültesi Dergisi, 41(2), 189-213.

Hunter, J.E. \& Schmidt, F.L. (2004). Methods of metaanalysis: Correcting error and bias in research findings (2.Bask1). California, Thousand Oaks: Sage Publications.

Ilies, R., Nahrgang, J.D, \& Morgeson, F. P. (2007). Leader-member exchange and citizenship behaviors: A meta-analysis. Journal of Applied Psychology, 92(1), 269-277.

Ilies, R., Fulmer, I. S., Spitzmuller, M., \& Johnson, M.D. (2009). Personality and citizenship behavior: The mediating role of job satisfaction. Journal of Applied Psychology, 94(4), 945- 959.

Karacaoğlu, K. \& Güney, Y.S. (2010). Öğretmenlerin örgütsel bağl1lıklarının, örgütsel vatandaşlık davranışları üzerindeki etkisi: Nevşehir ili örneği. Öneri Dergisi, 9(34), 137-153. 
Katz, D. (1964). The motivational basis of organizational behavior. Behavioral Science, 9(2), 131-133.

Lepine, J.A., Erez, A., \& Johnson, D.E. (2002). The nature and dimensionality of organizational citizenship behavior: A critical review and metaanalysis. Journal of Applied Psychology, 87(1), 5265 .

Lipsey, M.W. \& Wilson, D.B. (2001). Practical metaanalysis. Thousand Oaks, California: Sage Publications.

Mackenzie, S. B., Podsakoff, P.M., \& Fetter, R. (1991). Organizational citizenship behavior and objective productivity as determinants of managerial evaluations of salesperson's performance. Organizational Behavior and Human Decision Processes, 50(1), 123-150.

Mackenzie, S. B., Podsakoff, P.M., \& Ahearne, M. (1998). Some possible antecedents and consequences of in-role and extra-role salesperson performance. The Journal of Marketing, 62(3), 87-98.

Mathieu, J. E. \& Zajac, D. M. (1990). A Review and meta-analysis of the antecedents, correlates and consequences of organizational commitment. Psycological Bulletin, 108(2), 171-194.

Meyer, J. P. \& Allen, N. J. (1984). Testing the "side-bet theory" of organizational commitment: Some methodological considerations. Journal of Applied Psychology, 69(3), 372-378.

Meyer, J. P., Allen, N. J., \& Gellatly, I. R. (1990). Affective and continuance commitment to the organization: Evaluation of measures and analysis of concurrent and time - lagged reactions. Journal of Applied Psychology, 75(6), 710 - 720.

Meyer, J. P. \& Allen, N. J. (1991). A Three-component conceptualization of organizational commitment. Human Resource Management, 1(1), 61-89.

Meyer, J. P., Allen, N. J., \& Smith, C. (1993). Commitment to organizations and occupations: Extension and test of a three - component conceptualization. Journal of Applied Psychology, $78(4), 538-551$.

Meyer, J. P. \& Allen, N. J. (1997). Commitment in the workplace: Theory, research and application. Sage Publications: Thousand Oaks, California.

Meyer, J. P. \& Smith C. A. (2000). HRM practices and organizational commitment: Test of a mediation model. Canadian Journal of Administrative Sciences, 17(4), 319-331.

Meyer, J. P. \& Herscovitch, L. (2001). Commitment in the workplace: Toward a general model. Human Resource Management Review, 11(3), 299-326.
Meyer, J.P., Stanley, D.J., Herscovitch, L., \& Topolnytsky, L. (2002). Affective, continuance, and normative commitment to the organization: A metaanalysis of antecedents, correlates, and consequences. Journal of Vocational Behavior, 61, 20-52.

Meyer, J. P. \& Allen, N. J. (2004). TCM employee commitment survey academic users guide. Canada: Department of Psychology The University of Western Ontario

Meyer, J. P., Becker, T. E. \& Vandenberghe C. (2004). Employee commitment and motivation: A conceptual analysis and integrative model. Journal of Applied Psychology, 89(6), 991-1007.

Moorman, R. H., Niehoff, B. P., \& Organ D. W. (1993). Treating employees fairly and organizational citizenship behavior: Sorting the effects of job satisfaction, organizational commitment, and procedural justice. Employee Responsibilities and Rights Journal, 6(3), 209-225.

Morrison, E. W. (1994). Role definitions and organizational citizenship behavior: The importance of the employee's perspective. Academy of Management Journal, 37(6), 1543-1567.

Motowidlo, S. J. \& Van Scotter, J. R. (1994). Evidence that task performance should be distinguished from contextual performance. Journal of Applied Psychology, 79(4), 475-480.

Mowday, R. T., Steers, R. M., \& Porter, L. M. (1979). The measurement of organizational commitment. Journal of Vocational Behavior, 14(2), 224-247.

Mowday, R. T., Porter, L. M. \& Steers, R. M. (1982). Organizational linkages: The psychology of commitment, absenteeism, and turnover. New York: Academic Press.

Ngunia, S., Sleegers, P., \& Denessen, E. (2006). Transformational and transactional leadership effects on teachers' job satisfaction, organizational commitment, and organizational citizenship behavior in primary schools: The Tanzanian case. School Effectiveness and School Improvement, 17(2), 145177.

Obeng, K. \& Ugboro, I. (2003). Organizational commitment among public transit employees: An assessment study. Journal of The Transportation Research Forum, 57(2), 83-98.

O'reilly, C. \& Chatman, J. (1986). Organizational commitment and psychological attachment: The effects of compliance, identification, and internalization on prosocial behavior. Journal of Applied Psychology, 71(3), 492-499.

Organ, D.W. (1988). Organizational citizenship behavior: The good soldier syndrome. Lexington: 
Lexington Books.

Organ, D. W. (1990). The motivational basis of organizational citizenship behavior. Research in Organizational Behavior, 12, 43-72.

Organ, D.W. \& Ryan, K. (1995). A meta-analytic review of attitudinal and dispositional predictors of organizational citizenship behavior. Personnel Psychology, 48, 775-802.

Organ, D. W. (1997). Organizational citizenships behavior: It's construct cleanup time. Human Performance, 10(2), 85-97.

Özen, Ş. (2002). Türkiye'deki örgütler/yönetim araştırmalarında törensel görgülcülük sorunu. Yönetim Araştırmaları Dergisi, 2(2), 5-31.

Paine, J.B. \& Organ, D.W. (2000). The cultural matrix of organizational citizenship behavior: Some preliminary conceptual and empirical observations. Human Resource Management Review, 10(1), 45-59.

Pianluprasidh, P. (2005). The effect of perceived organizational support and organizational commitment on organizational citizenship behavior among nurses in Thailand (Yayınlanmamış Doktora Tezi). Alliant İnternational University, California,

Pigott, T. D. (2006). Book review: Methods of metaanalysis: Correcting error and bias in research findings. Evaluation and Program Planning, 29, 236237.

Podsakoff, P. M. \& Mackenzie, S. B. (1994). Organizational citizenship behaviors and sales unit effectiveness. Journal of Marketing Research, 31(3), 351-363.

Podsakoff, P.M., Mackenzie, S.B., Paine, J.B., \& Bachrach, D.G. (2000). Organizational citizenship behaviors: A critical review of the theoretical and empirical literature and suggestions for future research. Journal of Management, 26(3), 513-563.

Podsakoff, N.P., Whiting, S.W., Podsakoff, P.M., \& Blume, B.D. (2009). Individual - and organizational level consequences of organizational citizenship behaviors: A meta-analysis. Journal of Applied Psychology, 94(1), 122-141.

Riketta, M. (2002). Attitudinal organizational commitment and job performance: A meta-analysis. Journal of Organizational Behavior, 23(3), 257-266.

Shore, L. M. \& Wayne, S. J. (1993). Commitment and employee behavior: Comparison of affective commitment and continuance commitment with perceived organizational support. Journal of Applied Psychology, 78(5), 774-780.

Sığrı, Ü. (2007). İş görenlerin örgütsel bağl1lıklarının Meyer ve Allen tipolojisiyle analizi: Kamu ve özel sektörde karşlaştırmalı bir araştırma. Anadolu Üniversitesi Sosyal Bilimler Dergisi, 7(2), 261-278.

Smith, C. A., Organ, D. W. \& Near, J. P. (1983). Organizational citizenship behavior: Its nature and antecedents. Journal of Applied Psychology, 68(4), 653-663.

Somers, M. J. (1995). Organizational Commitment, Turnover and Absenteeism: An Examination of Direct and Interaction Effects. Journal of Organizational Behavior, 16(1),49-58.

Stum, D. L. (1999). Workforce commitment: Strategies for the new work order. Strategy and Leadership, 27(1), 4-7.

Şeşen, H. (2010). Kontrol odağı, genel öz yeterlilik, iş tatmini ve örgütsel adalet algısının örgütsel vatandaşlık davranışına etkisi: Ankara'da bulunan kamu kurumlarında bir araştırma. Hacettepe Üniversitesi Íktisadi ve İdari Bilimler Fakultesi Dergisi, 28(2), 195-220.

Şeşen, H. \& Basım, N. H. (2012). Impact of satisfaction and commitment on teachers' organizational citizenship. Educational Psychology, 32(4), 475-491.

Tansky, J. W. (1993). Justice and organizational citizenship behavior: What is the relationship? Employee Responsibilities and Rights Journal, 6(3), 195-207.

Tett, R. P. \& Meyer, J. P. (1993). Job satisfaction, organizational commitment, turnover intention, and turnover: Path analyses based on meta-analytic findings. Personnel Psychology, 46(2), 259-293.

Ünüvar, T. G. (2011). An integrative model of job characteristics, job satisfaction, organizational commitment, and organizational citizenship behavior (Yayınlanmamış Doktora Tezi). Orta Doğu Teknik Üniversitesi Sosyal Bilimler Enstitüsü, Ankara.

Vandenberghe, C. \& Tremblay, M. (2008). The role of pay satisfaction and organizational commitment in turnover intentions: A two-sample study. Journal of Business and Psychology, 22(3), 275-286.

Van Dyne, L., Cummings, L., \& Parks, J. M. (1995). Extra-role behaviors: In pursuit of construct and definitional clarity. Research in Organizational Behavior, 17, 215-285.

Van Scotter, J. R. (2000). Relationships of task performance and contextual performance with turnover, job satisfaction, and affective commitment. Human Resource Management Review, 10(1), 79-95.

Wasti, S. A. (2005). Commitment profiles: Combinations of organizational commitment forms and job outcomes. Journal of Vocational Behavior, 67, 290308. 
Wasti, S. A. \& Erdil, S. E. (2007). Bireycilik ve toplulukçuluk değerlerinin ölçülmesi: Benlik kurgusu ve Indcol ölçeklerinin Türkçe geçerlemesi. Yönetim Araştırmaları Dergisi, 7, (1-2), 39-66.

Wiener, Y. (1982). Commitment in organizations: A normative view. Academy of Management Review, 7(3), 418-428.

Williams, L. J. \& Anderson, S.E. (1991). Job satisfaction and organizational commitment as predictors of organizational citizenship and in-role behaviors. Journal of Management, 17(3), 601-617.

Y1lmaz, K. \& Bökeoğlu, O. Ç. (2008). Organizational citizenship behaviors and commitment in Turkish primary schools. World Applied Sciences Journal, 3(5), 775-780.

Y1lmazer, A. (2010). Örgütsel bağlılık ve ekstra rol davranışı arasındaki ilişkiler: İmalat sektöründe bir araştırma. Eskişehir Osmangazi Üniversitesi İ̈BF Dergisi, 5(2), 236-250. 